\title{
Regulacje prawa pracy sprzyjające realizacji obowiązków rodzicielskich w zakresie opieki nad dzieckiem
}

Jak pisał Jan Paweł II w encyklice Laborem exercens: „Praca stanowi podstawę kształtowania życia rodzinnego, które jest naturalnym prawem i powołaniem człowieka. Te dwa kręgi wartości - jeden związany z pracą, drugi wynikający z rodzinnego charakteru życia ludzkiego - muszą łączyć się z sobą prawidłowo i prawidłowo wzajemnie się przenikać. Praca jest poniekąd warunkiem zakładania rodziny, rodzina bowiem domaga się środków utrzymania, które w drodze zwyczajnej nabywa człowiek przez pracę"1 Pisząc o wzajemnych powiązaniach między życiem rodzinnym a pracą Ojciec święty wskazał na dwojakie znaczenie pracy. W pierwszym ujęciu praca ma służyć utrzymaniu rodziny, w drugim - ma urzeczywistniać cele rodziny, w tym w szczególności wychowanie (LE, s. 35).

Uznając rodzinę za jedną z podstawowych i najważniejszych wartości w życiu człowieka, Jan Paweł II podkreślił szczególną rolę kobiety w kształtowaniu prawidłowych relacji rodzinnych, które w istotny sposób wpływają na właściwe funkcjonowanie społeczeństwa. Jego zdaniem, nadrzędnym celem kobiety jest realizacja zadań wypływających z „posłannictwa macierzyńskiego”. Uwypuklając rolę matki dostrzegał jednak problematykę aktywności zawodowej kobiet. W tym kontekście przekonywał, że rzeczywisty „awans społeczny” kobiety wiąże się z taką strukturą pracy, „aby kobieta nie musiała zań płacić rezygnacją ze swojej specyficznej odrębności ze szkodą dla rodziny, w której jako matka posiada rolę niezastąpioną" (LE, s. 71).

* Dr Katarzyna Serafin, Katedra Prawa Pracy, Wydział Prawa i Administracji, Uniwersytet Łódzki, 90-232 Łódź, ul. Kopcińskiego 8/12.

1 JAN PaWEk II, Laborem exercens - O pracy ludzkiej, Wrocław 1995, s. 34 - cytaty opatrzone skrótem tytułu pochodzą z tego wydania. 
Zmiany społeczno-gospodarcze, jakie dokonały się na przestrzeni ostatnich kilkudziesięciu lat prowadzą do wniosku, że realizacja postulatów zawartych w cytowanej encyklice wymaga od ustawodawcy przyjęcia unormowań prawnych, umożliwiających łączenie obowiązków wynikających z bycia rodzicem z aktywnością zawodową. Należy przy tym podkreślić, że potrzeba rozwoju osobistego i chęć zrobienia kariery zawodowej to nie jedyne przyczyny leżące u podstaw znacznego wzrostu aktywności zawodowej kobiet w ostatnich kilku dziesięcioleciach. Bardzo istotnym czynnikiem wpływającym na zmiany w strukturze zatrudnienia jest wzrost kosztów utrzymania i spadek realnej wartości płac, czego istotną konsekwencją niejednokrotnie jest niemożność zaspokojenia podstawowych potrzeb rodziny, w której tylko jeden z jej członków osiąga dochód z pracy najemnej. Oznacza to, że podjęcie pracy zarobkowej przez kobietę często nie jest kwestią jej swobodnego wyboru, lecz wynika z konieczności podyktowanej troską o zapewnienie rodzinie godnych warunków życia.

Analizując regulacje polskiego prawa pracy można stwierdzić, że zawiera ono szereg rozmaitych rozwiązań sprzyjających łączeniu obowiązków wynikających z roli rodzica z aktywnością zawodową. Dokonując charakterystyki statusu prawnego pracującego rodzica, z uwagi na tytuł niniejszego opracowania ograniczę się wyłącznie do tych przepisów, które regulują sytuację pracownika już po narodzinach dziecka, pominę natomiast regulacje dotyczące uprawnień pracującej kobiety w związku z ciążą.

Problematyka uprawnień pracowniczych związanych ze sprawowaniem opieki nad dzieckiem została unormowana w dziale ósmym Kodeksu pracy zatytułowanym „Uprawnienia pracowników związane z rodzicielstwem”. Zawarte tam regulacje w omawianym zakresie dotyczą przede wszystkim zwolnień od pracy o różnym charakterze (krótszych, dłuższych, płatnych, niepłatnych, przysługujących jednemu bądź obojgu pracującym rodzicom).

Pierwszą kategorię uprawnień stanowią urlopy udzielane pracownikom w celu sprawowania osobistej opieki nad dzieckiem. Do tej grupy należy zaliczyć urlop macierzyński podstawowy i dodatkowy, urlop na warunkach urlopu macierzyńskiego, urlop rodzicielski, urlop ojcowski i urlop wychowawczy.

Urlop macierzyński przysługuje pracownicy co do zasady w związku z urodzeniem dziecka, jednak Kodeks pracy w art. $180 \S 3$ pozwala kobiecie wykorzystać nie więcej niż 6 tygodni takiego urlopu przed przewidywaną datą porodu. W obecnym stanie prawnym, wprowadzonym przez ustawę nowelizacyjną z dnia 6 grudnia 2008 r. ${ }^{2}$, podstawowy wymiar urlopu macierzyńskiego został uzależniony od liczby dzieci, które przyszły na świat przy jednym porodzie. W przypadku urodzenia jednego dziecka urlop wynosi 20 tygodni, w przypadku urodzenia dwojga dzieci - 31 tygodni, trojga - 33 tygodnie, czworga - 35 tygodni, i wreszcie w przypadku urodzenia pięciorga i więcej dzieci przy jednym porodzie - 37 tygodni.

2 Ustawa z 6 grudnia 2008 r. o zmianie ustawy - Kodeks pracy oraz niektórych innych ustaw, Dz. U. 2008, nr 237, poz. 1654. 
Urlop macierzyński jest urlopem obligatoryjnym, a jego udzielenie nie jest uzależnione od spełnienia przez pracownicę dodatkowych, innych niż urodzenie dziecka, warunków. Kodeks pracy pozwala jednak pracownicy zrezygnować z części urlopu macierzyńskiego po wykorzystaniu przez nią po porodzie co najmniej 14 tygodni tego urlopu. Zatem w zakresie owych 14 tygodni pracodawca ma bezwzględny obowiązek udzielenia pracownicy urlopu macierzyńskiego ${ }^{3}$. Ma to związek $z$ jedną $z$ funkcji tego urlopu. Bliski kontakt $z$ matką w pierwszych tygodniach po urodzeniu jest bardzo ważny dla prawidłowego rozwoju dziecka. Stąd, sprawowanie opieki nad dzieckiem jest jednym z celów tego urlopu, ale nie jedynym. Zwolnienie od pracy w trakcie urlopu macierzyńskiego ma także istotne znaczenie dla młodej mamy ze względów zdrowotnych. Jest to czas przeznaczony przede wszystkim na regenerację organizmu kobiety i powrót do równowagi po stanie ciąży i porodzie, co należy uznać za pierwotny cel urlopu macierzyńskiego. Wskazują na to regulacje dotyczące pracownicy, która urodziła martwe dziecko bądź dziecko, które zmarło przed upływem 8 tygodni życia. Zgodnie $z$ art. $180^{1} \S 1$ k.p., urlop macierzyński również w takich wypadkach przysługuje kobiecie, a jego wymiar wynosi 8 tygodni po porodzie. Pracownica ma również prawo do 8 tygodni urlopu macierzyńskiego w sytuacji, kiedy dziecko po porodzie wymaga opieki szpitalnej. W tym ostatnim wypadku osiem tygodni po porodzie kobieta musi wykorzystać mimo pobytu dziecka w szpitalu. Pozostała część urlopu może być natomiast wykorzystana przez pracownicę w terminie późniejszym, po wyjściu dziecka ze szpitala. Ponadto, ustawodawca przyznał prawo do urlopu macierzyńskiego w wymiarze nie niższym niż 8 tygodni po porodzie pracownicy, która po urodzeniu dziecka rezygnuje $z$ jego wychowania i oddaje je innej osobie w celu przysposobienia lub do domu małego dziecka (art. 182 k.p.).

Zasadniczo prawo do urlopu macierzyńskiego przysługuje matce dziecka. Jednak kodeks przewiduje również przypadki, w których z urlopu macierzyńskiego będzie mógł skorzystać ojciec dziecka. Prawo do urlopu macierzyńskiego przysługuje pracownikowi będącemu ojcem dziecka w sytuacji zgonu matki w trakcie trwania tego urlopu. Ojciec może również wykorzystać część urlopu macierzyńskiego przypadającą na czas pobytu matki dziecka w szpitalu ze względu na jej stan zdrowia uniemożliwiający sprawowanie osobistej opieki nad dzieckiem. W obu sytuacjach prawo do korzystania z urlopu macierzyńskiego przechodzi niejako „automatycznie” na ojca dziecka, bez konieczności podejmowania dodatkowych czynności w tym zakresie, w szczególności nie jest ono uzależnione od wcześniejszego uzyskania zgody matki dziecka..

Nieco inna sytuacja została unormowana w art. $180 \S 5$ i 6 k.p. Przepisy te zakładają możliwość wykorzystania przez pracownika ojca wychowującego dziecko części urlopu macierzyńskiego, z której zrezygnowała matka dziecka. W tym przypadku skorzystanie przez pracownika z urlopu macierzyńskiego

${ }^{3}$ Wyjątkiem jest sytuacja, gdy całkowity wymiar urlopu macierzyńskiego jest niższy niż 14 tygodni, o czym będzie jeszcze mowa później. 
wymaga spełnienia dwóch warunków. Po pierwsze, matka dziecka musi zrezygnować z części urlopu macierzyńskiego, przy czym należy podkreślić, że jest to dobrowolna decyzja pracownicy. Po drugie, pracownik razem z oświadczeniem matki dziecka o rezygnacji z części urlopu musi złożyć u swojego pracodawcy wniosek o udzielenie części urlopu pozostałej do wykorzystania. Uzależnienie możliwości skorzystania przez pracownika ojca z urlopu macierzyńskiego od wcześniejszej rezygnacji z takiego urlopu matki dziecka jest oczywiste. Jednak $z$ brzmienia art. $180 \S 6$ k.p. można wywnioskować, że ta zależność działa również w odwrotnym kierunku. Przepis ten bowiem wymaga, by do wniosku o rezygnację z części urlopu pracownica dołączyła zaświadczenie pracodawcy zatrudniającego ojca wychowującego dziecko, które potwierdza termin rozpoczęcia przez pracownika urlopu macierzyńskiego wskazany w jego wniosku o udzielenie tego urlopu, przypadający bezpośrednio po terminie rezygnacji z części urlopu przez matkę. Wynika stąd, że podstawowy urlop macierzyński musi być wykorzystany w pełnym wymiarze.

Kodeks pracy przewiduje także dodatkowy urlop macierzyński. Jest to stosunkowo nowa instytucja prawna, którą wprowadziła do polskiego prawa pracy w roku 2008 wspomniana już wcześniej ustawa nowelizacyjna. Urlop ten ma jednak nieco inny charakter niż podstawowy urlop macierzyński. Zgodnie $z$ art. $182^{1}$ k.p., dodatkowego urlopu macierzyńskiego udziela się jednorazowo albo w dwóch częściach, przypadających bezpośrednio jedna po drugiej, w wymiarze tygodnia lub jego wielokrotności bezpośrednio po wykorzystaniu podstawowego urlopu macierzyńskiego ${ }^{4}$. Należy zatem przyjąć, że minimalny wymiar dodatkowego urlopu macierzyńskiego wynosi jeden tydzień, a maksymalny jest uzależniony od tego, ile dzieci przyszło na świat przy jednym porodzie. W przypadku urodzenia jednego dziecka wymiar dodatkowego urlopu macierzyńskiego w chwili wejścia w życie niniejszej regulacji (1 stycznia 2010 r.) wynosił maksymalnie 2 tygodnie, zaś w przypadku urodzenia więcej niż jednego dziecka maksymalnie 3 tygodnie. Zgodnie z przepisami ustawy nowelizacyjnej, wymiar ten miał być stopniowo wydłużany, by docelowo w 2014 r. osiągnąć odpowiednio 6 i 8 tygodni 5 .

Jak już wcześniej wskazałam, mimo podobnego celu charakter prawny obu urlopów jest różny. Dodatkowy urlop macierzyński może być udzielony pracownicy lub pracownikowi ojcu wychowującemu dziecko. Wypada przy tym zaznaczyć, że z urlopu tego nie mogą korzystać jednocześnie oboje rodzice. Mogą się jednak nim podzielić w ten sposób, że jedną część wykorzysta matka dziecka, a drugą ojciec. Urlop ten jest udzielany wyłącznie na pisemny wniosek osoby

\footnotetext{
${ }^{4}$ Możliwość podzielenia urlopu na dwie części wprowadziła ustawa z dnia 28 maja 2013 r. o zmianie ustawy - Kodeks pracy oraz niektórych innych ustaw, Dz. U. 2013, poz. 675.

${ }_{5}$ Należy w tym miejscu uściślić, że ustawa z dnia 28 maja 2013 r. o zmianie ustawy - Kodeks pracy oraz niektórych innych ustaw, Dz. U. 2013, poz. 675, wchodząca w życie dnia 17 czerwca 2013 r., zmieniła brzmienie art. $182^{1}$ k.p., wprowadzając m.in. do treści tego przepisu już tylko wymiar 6 i 8 tygodni dodatkowego urlopu macierzyńskiego.
} 
ubiegającej się o jego wykorzystanie, a więc nie ma charakteru obligatoryjnego. Jeśli jednak wniosek o jego wykorzystanie zostanie złożony, to bezwzględnie wiąże pracodawcę. Wniosek o udzielenie dodatkowego urlopu macierzyńskiego powinien być złożony w terminie nie krótszym niż 14 dni przed rozpoczęciem korzystania z tego urlopu. Należy w nim określić wymiar urlopu, z którego pracownica (albo pracownik) chce skorzystać oraz termin zakończenia podstawowego urlopu macierzyńskiego. Ponadto, w przypadku, gdy wniosek dotyczy drugiej części dodatkowego urlopu macierzyńskiego, należy w nim wskazać termin zakończenia pierwszej części urlopu oraz okres urlopu wykorzystanego do tej pory.

Kolejną cechą charakterystyczną dodatkowego urlopu macierzyńskiego, odróżniającą go od urlopu podstawowego, jest możliwość połączenia go z wykonywaniem pracy w niepełnym wymiarze czasu pracy u pracodawcy udzielającego takiego urlopu ${ }^{6}$. Przepisy zezwalają bowiem na wykonywanie pracy w trakcie korzystania z dodatkowego urlopu macierzyńskiego w wymiarze nie wyższym niż połowa pełnego wymiaru czasu pracy. Osoba korzystająca z urlopu określa w stosownym wniosku wymiar czasu pracy i okres łączenia dodatkowego urlopu macierzyńskiego z wykonywaniem pracy. Należy przy tym podkreślić, że decyzja o łączeniu urlopu ze świadczeniem pracy nie musi być podjęta równocześnie $z$ decyzją o skorzystaniu z dodatkowego urlopu macierzyńskiego, bowiem zgodnie z art. $182^{1} \S 6$ k.p., podjęcie pracy następuje na pisemny wniosek składany w terminie nie krótszym niż 14 dni przed rozpoczęciem wykonywania pracy. Wniosek ten ma dla pracodawcy charakter wiążący - co do zasady musi go uwzględnić, chyba że jest to niemożliwe ze względu na organizację pracy bądź rodzaj pracy wykonywanej przez pracownika. W takim przypadku pracodawca ma obowiązek poinformować pracownika na piśmie o przyczynie odmowy uwzględnienia wniosku.

Zarówno w czasie korzystania z urlopu podstawowego, jak i dodatkowego urlopu macierzyńskiego pracownicy (pracownikowi) przysługuje zasiłek macierzyński z ubezpieczenia społecznego na zasadach określonych w ustawie z dnia 25 czerwca 1999 r. o świadczeniach pieniężnych z ubezpieczenia społecznego w razie choroby i macierzyństwa ${ }^{7}$. Wysokość zasiłku jest równa kwocie 100\% lub $80 \%$ wynagrodzenia (w zależności od trybu udzielania), jednak w przypadku łączenia dodatkowego urlopu macierzyńskiego z zatrudnieniem w niepełnym wymiarze czasu pracy u pracodawcy, który udzielił urlopu, wysokość zasiłku pomniejsza się proporcjonalnie do wymiaru czasu pracy, w którym pracownik łączy korzystanie $z$ dodatkowego urlopu macierzyńskiego $z$ wykonywaniem pracy u tego pracodawcy ${ }^{8}$.

${ }_{6}$ Wprawdzie żaden przepis Kodeksu pracy wyraźnie nie zabrania podejmowania pracy w czasie trwania podstawowego urlopu macierzyńskiego, niemniej jednak kłóciłoby się to z podstawowym celem tego urlopu, jakim jest regeneracja sił po przebytym porodzie i powrót organizmu kobiety do stanu fizjologicznego sprzed ciąży. Podjęcie pracy mogłoby ten czas znacznie wydłużyć niosąc ze sobą ryzyko spowodowania komplikacji zdrowotnych.

7 Dz. U. 2005, nr 3, poz. 267 ze zm.

8 Zgodnie z art. 29 ust. 7 ustawy z 25 czerwca 1999 r., t. jedn., Dz. U. 2005, nr 31, poz. 267 ze zm. 
Polski ustawodawca przyznał prawo do analogicznych urlopów także takim pracownikom, którzy wychowują dziecko nie będąc jego biologicznymi rodzicami. Zgodnie z przepisami Kodeksu pracy, pracownik przyjmujący dziecko na wychowanie ma prawo do urlopu na warunkach urlopu macierzyńskiego. Urlop ten przysługuje dwóm kategoriom pracowników - pracownikom, którzy przyjęli dziecko na wychowanie i wystąpili do sądu opiekuńczego z wnioskiem o wszczęcie postępowania w sprawie przysposobienia dziecka oraz pracownikom przyjmującym dziecko na wychowanie w ramach rodziny zastępczej, z wyjątkiem rodziny zastępczej zawodowej.

Od 1 stycznia 2009 r. wymiar urlopu na warunkach urlopu macierzyńskiego jest uzależniony od liczby dzieci przyjętych przez pracownika na wychowanie i kształtuje się analogicznie do urlopu macierzyńskiego. Zgodnie z art. $183 \S 1$ k.p., wymiar urlopu wynosi 20 tygodni w przypadku przyjęcia jednego dziecka na wychowanie, 31 tygodni w przypadku jednoczesnego przyjęcia dwojga dzieci na wychowanie, 33 tygodnie w przypadku jednoczesnego przyjęcia trojga dzieci, 35 tygodni w przypadku jednoczesnego przyjęcia czworga dzieci i 37 tygodni w przypadku jednoczesnego przyjęcia pięciorga i więcej dzieci na wychowanie, nie dłużej jednak niż do ukończenia przez dziecko 7 roku życia, zaś w przypadku dziecka, wobec którego podjęto decyzję o odroczeniu obowiązku szkolnego, nie dłużej niż do ukończenia przez nie 10 roku życia. Jeśli natomiast pracownik przyjął na wychowanie dziecko w wieku do 7 roku życia lub dziecko do 10 roku życia, wobec którego podjęto decyzję o odroczeniu obowiązku szkolnego, urlop na warunkach urlopu macierzyńskiego jest krótszy. Przysługuje wtedy w wymiarze 9 tygodni.

Powoływana już wcześniej ustawa nowelizacyjna z 6 grudnia 2008 r. także pracownikom przyjmującym dziecko na wychowanie dała możliwość skorzystania z fakultatywnego dodatkowego urlopu na warunkach urlopu macierzyńskiego. Wymiar urlopu jest uzależniony od liczby i wieku dzieci przyjętych na wychowanie. Podobnie jak w przypadku dodatkowego urlopu macierzyńskiego, tak i tutaj ustawa zakłada stopniowe wydłużanie wymiaru urlopu. W dniu wejścia w życie przepisów regulujących tę instytucję wymiar urlopu w przypadku pojedynczej adopcji wynosił maksymalnie dwa tygodnie, przy jednoczesnym przyjęciu na wychowanie dwojga lub więcej dzieci maksymalnie trzy tygodnie, a w przypadku adopcji dziecka w wieku do 7 roku życia lub do 10 roku życia, gdy podjęto decyzję o odroczeniu obowiązku szkolnego, wymiar urlopu wynosił jeden tydzień. W latach 2012-2013 wymiar urlopu wynosił maksymalnie odpowiednio cztery, sześć i dwa tygodnie, by docelowo w roku 2014 osiągnąć wymiar sześciu, ośmiu i trzech tygodni ${ }^{9}$. Zasady korzystania z dodatkowego urlopu na warunkach urlopu macierzyńskiego są takie same, jak w przypadku dodatkowego urlopu macierzyńskiego. Oznacza to,

${ }^{9}$ Również w odniesieniu do tego urlopu cytowana już ustawa z dnia 28 maja 2013 r., Dz. U. 2013, poz. 675 , zmieniła brzmienie przepisu m.in. w zakresie jego maksymalnego wymiaru, wskazując tylko wymiar 6,8 i 3 tygodni. 
że urlop ten może być udzielany jednorazowo albo w dwóch częściach, przypadających bezpośrednio jedna po drugiej w wymiarze tygodnia lub jego wielokrotności na pisemny wniosek pracownika. Ponadto można go łączyć z wykonywaniem pracy w niepełnym wymiarze czasu pracy u pracodawcy, który takiego urlopu udzielił.

Podobnie jak pracownikom będącym rodzicami biologicznymi, także pracownikom przyjmującym dziecko na wychowanie w trakcie korzystania z urlopu na warunkach urlopu macierzyńskiego, zarówno w wariancie podstawowym, jak i dodatkowym, przysługuje zasiłek macierzyński.

Okres sprawowania opieki nad dzieckiem można przedłużyć, korzystając z najnowszej instytucji prawa pracy w zakresie uprawnień związanych z rodzicielstwem, czyli urlopu rodzicielskiego. Został on wprowadzony do Kodeksu pracy ustawą z dnia 28 maja 2013 r. o zmianie ustawy Kodeks pracy oraz niektórych innych ustaw ${ }^{10}$. Zgodnie $z$ wolą ustawodawcy, urlop rodzicielski daje pracownikowi możliwość wydłużenia płatnego okresu sprawowania opieki nad dzieckiem, stąd jedyną przesłanką nabycia prawa do tego urlopu jest uprzednie wykorzystanie urlopu macierzyńskiego podstawowego i dodatkowego w pełnym wymiarze. Urlop ten jest udzielany na wniosek i przysługuje pracownikowi w wymiarze maksymalnie 26 tygodni bez względu na liczbę dzieci, które przyszły na świat przy jednym porodzie. Zgodnie z przepisami kodeksu, urlop rodzicielski może być udzielony jednorazowo albo w nie więcej niż trzech częściach. W tym drugim wypadku muszą być jednak spełnione dwa warunki. Po pierwsze, części urlopu należy wykorzystać bezpośrednio jedna po drugiej, co oznacza, że nie może być między nimi ani jednego dnia przerwy. Po drugie, żadna z części nie może trwać krócej niż 8 tygodni.

Co do zasady, z urlopu może korzystać zarówno matka, jak i ojciec dziecka. W równym stopniu dotyczy to rodziców biologicznych i adopcyjnych. Kodeks pracy przewiduje w tym zakresie różne warianty korzystania z urlopu. Na przykład, w przypadku podzielenia urlopu na części rodzice mogą korzystać z niego wymiennie. Możliwe jest także jednoczesne korzystanie $z$ tego urlopu przez oboje rodziców z zastrzeżeniem, że łączny wymiar urlopu nie może przekroczyć 26 tygodni, co w rezultacie oznacza skrócenie faktycznego okresu sprawowania opieki nad dzieckiem ${ }^{11}$.

Chociaż prawo do urlopu rodzicielskiego zostało przyznane zarówno matce, jak i ojcu dziecka, to wydaje się, że decyzja o tym, które z rodziców i w jakim zakresie będzie korzystać $z$ tego urlopu, należy w przeważającej mierze do matki dziecka. Kodeks przewiduje bowiem dwa alternatywne tryby udzielania tego urlopu rzutujące ponadto na wysokość zasiłku macierzyńskiego. Pierwszy $z$ trybów został uregulowany $w$ art. $179^{1}$ k.p. Zgodnie $z$ tym przepisem, matka

10 Dz. U. 2013, poz. 675.

${ }^{11}$ W takim wypadku okresy korzystania z urlopu przez każdego z rodziców podlegają zsumowaniu. 
dziecka nie później niż 14 dni po porodzie może złożyć wniosek o udzielenie jej bezpośrednio po urlopie macierzyńskim dodatkowego urlopu macierzyńskiego w pełnym wymiarze, a bezpośrednio po nim urlopu rodzicielskiego w pełnym wymiarze $^{12}$. W takim przypadku przez cały okres korzystania ze wszystkich wyżej wymienionych urlopów będzie jej przysługiwał zasiłek macierzyński w stałej wysokości stanowiącej równowartość $80 \%$ wynagrodzenia. Przepisy dają matce możliwość późniejszej rezygnacji z urlopu rodzicielskiego, który będzie mógł wtedy wykorzystać ojciec dziecka, ale trzeba podkreślić, że zasiłek macierzyński wypłacany przez czas korzystania z urlopu rodzicielskiego wyniesie $w$ takiej sytuacji tylko $60 \%$ wynagrodzenia.

Drugi tryb, przewidziany w art. $182^{1 a}$ k.p., daje możliwość złożenia wniosku o urlop rodzicielski $w$ terminie późniejszym. $Z$ reguły nastąpi to w czasie korzystania $z$ dodatkowego urlopu macierzyńskiego, gdyż wniosek o udzielenie urlopu rodzicielskiego należy złożyć $w$ terminie nie krótszym niż 14 dni przed rozpoczęciem korzystania z tego urlopu. Wniosek taki może złożyć matka bądź ojciec dziecka bez względu na to, które z rodziców korzysta z dodatkowego urlopu macierzyńskiego. W czasie trwania urlopu rodzicielskiego, udzielonego w tym trybie, pracownikowi korzystającemu z takiego urlopu będzie przysługiwał zasiłek macierzyński w wysokości $60 \%$ wynagrodzenia.

Urlop rodzicielski, podobnie jak dodatkowy urlop macierzyński, można łączyć $z$ wykonywaniem pracy u pracodawcy udzielającego tego urlopu w wymiarze nie wyższym niż pół etatu.

Ostatni z płatnych urlopów związanych z rodzicielstwem to urlop ojcowski. Został on wprowadzony do Kodeksu pracy wspomnianą już wcześniej ustawą nowelizacyjną z 6 grudnia 2008 r. Jest to własne uprawnienie pracownika ojca, niezależne od innych urlopów związanych z rodzicielstwem. Intencją ustawodawcy było wyrównanie, przynajmniej w pewnym zakresie, naturalnej dysproporcji świadczeń rodzicielskich kobiet i mężczyzn oraz umożliwienie mężczyźnie bliższego kontaktu z dzieckiem w pierwszych miesiącach życia. Urlop ten przysługuje pracownikowi ojcu wychowującemu dziecko w wymiarze dwóch tygodni ${ }^{13}$.

W aktualnym brzmieniu przepisu, nadanym przez nowelizację Kodeksu pracy $z$ dnia 25 listopada 2010 r. $^{14}$, uprawnienie to przyznaje się zarówno ojcu biologicznemu, jak i pracownikowi, który przysposobił dziecko. Z urlopu ojcowskiego pracownik może skorzystać do ukończenia przez dziecko 12 miesiąca życia (w przypadku ojca biologicznego), albo do upływu 12 miesięcy od dnia uprawomocnienia się postanowienia orzekającego przysposobienie i nie dłużej

${ }^{12}$ W odniesieniu do rodziców adopcyjnych termin czternastodniowy liczy się od przyjęcia dziecka na wychowanie i wystąpienia do sądu opiekuńczego z wnioskiem o wszczęcie postępowania w sprawie przysposobienia dziecka lub od przyjęcia dziecka na wychowanie jako rodzina zastępcza, z wyjątkiem rodziny zastępczej zawodowej.

13 Taki wymiar urlopu przysługuje pracownikowi od 1 stycznia 2012 r. Od czasu wejścia w życie tej regulacji prawnej (1 stycznia 2010 r.) do końca roku 2011 wymiar urlopu ojcowskiego wynosił jeden tydzień.

14 Dz. U. 2010, nr 249, poz. 1655. 
niż do ukończenia przez dziecko 7 roku życia, a w przypadku dziecka, wobec którego podjęto decyzję o odroczeniu obowiązku szkolnego - nie dłużej niż do ukończenia przez nie 10 roku życia. Urlop ojcowski jest udzielany na pisemny wniosek pracownika, który należy złożyć w terminie nie krótszym niż 7 dni przed rozpoczęciem korzystania z urlopu. Wniosek pracownika jest wiążący dla pracodawcy.

Poza płatnymi urlopami związanymi z rodzicielstwem Kodeks pracy przewiduje także bezpłatny urlop wychowawczy. Z urlopu takiego może skorzystać matka lub ojciec dziecka pod warunkiem posiadania co najmniej sześciomiesięcznego stażu pracy, przy czym do okresu tego wliczane są również poprzednie okresy zatrudnienia. Ustawodawca wyraźnie określił cel tego urlopu - jest on udzielany pracownikowi w celu sprawowania osobistej opieki nad dzieckiem. Jest to najdłuższy z urlopów związanych z rodzicielstwem - przysługuje co do zasady w wymiarze do trzydziestu sześciu miesięcy, nie dłużej jednak niż do ukończenia przez dziecko piątego roku życia. Pracownik może też skorzystać z urlopu wychowawczego w wymiarze do trzydziestu sześciu miesięcy, nie dłużej niż do ukończenia przez dziecko 18 roku życia, jeśli z powodu stanu zdrowia dziecka potwierdzonego orzeczeniem o niepełnosprawności lub stopniu niepełnosprawności dziecko wymaga osobistej opieki pracownika. Co ważne, okres urlopu wychowawczego, w dniu jego zakończenia, wlicza się do okresu, od którego zależą uprawnienia pracownicze.

Urlopu wychowawczego udziela się na pisemny wniosek pracownika, który powinien być złożony na dwa tygodnie przed terminem rozpoczęcia urlopu określonym we wniosku. Wniosek taki jest wiążący dla pracodawcy. Zważywszy, że urlop wychowawczy może być wykorzystany w częściach (maksymalnie pięciu) pracownik we wniosku powinien wskazać datę rozpoczęcia i zakończenia urlopu wychowawczego oraz okres urlopu, który dotychczas został wykorzystany na dane dziecko. Zgodnie z przepisami wykonawczymi dotyczącymi urlopu wychowawczego, pracodawca udziela urlopu wychowawczego na okres wskazany we wniosku pracownika ${ }^{15}$. Z powyższego wynika, że to do pracownika należy decyzja, jak długo będzie korzystał z urlopu wychowawczego. Wyjątek stanowi sytuacja, w której wniosek o udzielenie urlopu wychowawczego został złożony po dokonaniu czynności prawnej zmierzającej do rozwiązania umowy o pracę. W tym przypadku wniosek ma również charakter wiążący, ale pracodawca udziela pracownikowi urlopu na okres nie dłuższy niż do dnia rozwiązania umowy o pracę wskutek dokonanej czynności.

Biorąc pod uwagę fakt, że urlop wychowawczy może być udzielony na stosunkowo długi okres, w praktyce może zdarzyć się, że pracownik przebywający na takim urlopie nie będzie chciał z różnych przyczyn dłużej z niego korzystać. Uwzględniając taką ewentualność ustawodawca dał pracownikowi możliwość rezygnacji z urlopu. Zgodnie z art. $186^{3}$ k.p., pracownik może zrezygnować

15 Rozporządzenie Ministra Gospodarki, Pracy i Polityki Społecznej z 19 września 2013 r. w sprawie szczegółowych warunków udzielania urlopu wychowawczego, Dz. U. 2013, poz. 1139. 
z urlopu w każdym czasie pod warunkiem uzyskania zgody pracodawcy albo po uprzednim zawiadomieniu pracodawcy najpóźniej na 30 dni przed terminem zamierzonego podjęcia pracy. W tym ostatnim wypadku zgoda pracodawcy nie jest wymagana, decyzja pracownika jest bowiem wiążąca dla pracodawcy. Termin trzydziestodniowy ma służyć pracodawcy na przygotowanie się do ponownego podjęcia pracy przez pracownika.

W obecnym brzmieniu przepisy Kodeksu pracy nie przyznają pierwszeństwa w ubieganiu się o urlop wychowawczy pracownicy będącej matką dziecka. Nie ma znaczenia, które z rodziców występuje z wnioskiem o udzielenie takiego urlopu. Poza tym Kodeks pracy zezwala na jednoczesne korzystanie $z$ takiego urlopu obojgu rodzicom przez okres nieprzekraczający czterech miesięcy. Co więcej, ustawa nowelizacyjna z dnia 26 lipca 2013 r. ${ }^{16}$ wprowadziła do Kodeksu pracy wyłączne prawo do skorzystania z urlopu wychowawczego w wymiarze jednego miesiąca dla każdego z rodziców. Oznacza to, że w praktyce w przypadku korzystania przez jednego $z$ rodziców z urlopu wychowawczego maksymalny okres tego urlopu wynosi 35 miesięcy. Urlop w pełnym wymiarze 36 miesięcy jest możliwy do wykorzystania przez jednego z rodziców tylko w przypadkach enumeratywnie wyliczonych w ustawie - jeżeli drugi rodzic dziecka nie żyje, nie przysługuje mu władza rodzicielska, został jej pozbawiony albo władza taka uległa ograniczeniu lub zawieszeniu. Urlop w pełnym wymiarze przysługuje również w sytuacji, gdy dziecko pozostaje pod opieką jednego opiekuna.

Jak już wcześniej wspomniałam, urlop wychowawczy jest udzielany pracownikowi w celu sprawowania osobistej opieki nad dzieckiem. Nie wyklucza to jednak łączenia takiego urlopu z aktywnością zawodową. Ustawodawca przyznał pracownikowi korzystającemu z urlopu wychowawczego prawo do podjęcia pracy zarobkowej u dotychczasowego lub innego pracodawcy. Pracownik może też podjąć inną działalność, a także naukę lub szkolenie. Jest to zrozumiałe zważywszy, że urlop wychowawczy jest urlopem bezpłatnym. Wspomnieć jednak należy, że powyższa aktywność pracownika w czasie trwania urlopu wychowawczego jest dozwolona pod warunkiem, że nie wyłącza możliwości sprawowania osobistej opieki nad dzieckiem. Jeśli pracodawca ustali, że pracownik trwale zaprzestał sprawowania osobistej opieki nad dzieckiem, to zgodnie z art. $186^{2} \S 2$ k.p., wzywa pracownika do stawienia się do pracy w terminie przez siebie ustalonym, ale nie później niż w ciągu 30 dni od dnia powzięcia takiej wiadomości i nie wcześniej niż po upływie 3 dni od dnia wezwania.

Urlop wychowawczy ma charakter fakultatywny - pracownik może z niego skorzystać, ale nie musi. Mając na względzie fakt, że brak dochodów w czasie korzystania z urlop wychowawczego może skłaniać pracownika do rezygnacji z tego uprawnienia, ustawodawca przewidział jeszcze inną możliwość, z której

16 Dz. U. 2013, poz. 1028. 
pracownik może skorzystać. Zgodnie z art. $186^{7} \S 1$ k.p., pracownik uprawniony do urlopu wychowawczego może złożyć pisemny wniosek o obniżenie wymiaru czasu pracy do wymiaru nie niższego niż pół etatu w okresie, w którym mógłby korzystać z urlopu wychowawczego. Taki wniosek, podobnie jak wniosek o udzielenie urlopu wychowawczego, jest wiążący dla pracodawcy. Powyższe rozwiązanie $z$ jednej strony daje pracownikowi w pewnym zakresie możliwość sprawowania osobistej opieki nad dzieckiem, zaś z drugiej - pozwala mu osiągać jakiś dochód, co może przyczynić się do poprawy sytuacji materialnej jego rodziny.

W dziale ósmym Kodeksu pracy, poza wymienionymi urlopami, przewidziane są jeszcze krótkie płatne zwolnienia od pracy, związane ze sprawowaniem obowiązków rodzicielskich. Pierwsze ze zwolnień przewidziane jest zarówno dla pracowników będących biologicznymi rodzicami dziecka, jak i dla rodziców adopcyjnych. Zgodnie $z$ art. 188 k.p., pracownikowi wychowującemu przynajmniej jedno dziecko do lat 14 przysługuje płatne zwolnienie od pracy w wymiarze dwóch dni w ciągu roku kalendarzowego. Należy przy tym zaznaczyć, że z tego uprawnienia może skorzystać tylko jedno z rodziców. W literaturze pojawiają się poglądy, że zwolnienie to w obecnym kształcie nie pełni już takiej roli społeczno-gospodarczej, dla jakiej zostało powołane. Pracodawca nie ma bowiem prawnej możliwości kontroli, czy te dni wolne rzeczywiście zostały wykorzystane w celu sprawowania opieki nad dzieckiem ${ }^{17}$.

Drugie zwolnienie, o bardzo specyficznym charakterze, przysługuje wyłącznie pracownicy będącej matką biologiczną dziecka. Chodzi o przerwy na karmienie piersią. Zgodnie $z$ art. 187 k.p., przysługują one pracownicy karmiącej dziecko piersią, zatrudnionej na czas dłuższy niż cztery godziny dziennie. Jeśli pracownica karmi jedno dziecko, przysługują jej dwie półgodzinne przerwy wliczane do czasu pracy, zaś w przypadku karmienia więcej niż jednego dziecka, długość każdej z przerw wzrasta do 45 minut. Na wniosek pracownicy przerwy te mogą być jej udzielane łącznie. W praktyce oznacza to najczęściej, że pracownica później zaczyna albo wcześniej kończy pracę. Jeśli czas pracy pracownicy nie przekracza sześciu godzin dziennie, przysługuje jej jedna przerwa (półgodzinna lub czterdziestopięciominutowa w zależności od liczby dzieci karmionych piersią).

Kolejne uprawnienie pracownicze o innym charakterze niż urlopy związane z rodzicielstwem i zwolnienia od pracy przybiera postać zakazu adresowanego do pracodawcy. Chodzi tu o zakaz zatrudniania pracowników opiekujących się dzieckiem do lat czterech w godzinach nadliczbowych, w porze nocnej, w systemie przerywanego czasu pracy oraz o zakaz delegowania pracownika poza stałe miejsce pracy. Celem ustanowienia powyższych zakazów było uchronienie

17 M. Latos-Mıkowska, Przemiany stosunku pracy związane z rodzicielstwem, [w:] Współczesne problemy prawa pracy i ubezpieczeń społecznych, red. L. Florek, Ł. Pisarczyk, Warszawa 2011, s. 227. Autorka wskazuje, że pracownicy najczęściej traktują te dni jako przedłużenie urlopu wypoczynkowego. Jej zdaniem cel, jakiemu miały służyć tzw. „dni na dziecko” obecnie może być realizowany w drodze tzw. urlopu na żądanie. 
pracowników przed dodatkowymi utrudnieniami w sprawowaniu osobistej opieki nad dzieckiem, jakie łączą się z wykonywaniem pracy we wskazanych warunkach. Zakazy te jednak nie mają charakteru bezwzględnego - uchyla je zgoda pracownika. Dodać przy tym należy, że w przypadku, gdy oboje rodzice dziecka lub jego opiekunowie są zatrudnieni, z prawa odmowy świadczenia pracy w godzinach nadliczbowych, porze nocnej, systemie przerywanego czasu pracy oraz delegowania poza stałe miejsce pracy może skorzystać tylko jedno $z$ nich.

Korzystanie przez pracownika z uprawnień związanych z rodzicielstwem dla pracodawcy zwykle łączy się z obciążeniami o różnym charakterze. Nie ulega wątpliwości, że w tej sytuacji byłby on skłonny pozbyć się takiego pracownika - „wymienić” go na kogoś bardziej dyspozycyjnego i efektywnego. Stąd, korzystanie z przywilejów związanych z rodzicielstwem musi być zabezpieczone przed ewentualnością utraty pracy lub pogorszeniem sytuacji pracownika. Ustawodawca przyznaje taką ochronę pracownikom korzystającym z urlopów związanych $z$ rodzicielstwem. Realizowana jest ona za pomocą instytucji dwojakiego rodzaju - szczególnej ochrony trwałości stosunku pracy, polegającej na zakazie wypowiedzenia i rozwiązania umowy o pracę przez pracodawcę oraz gwarancji powrotu na stanowisko pracy po zakończeniu korzystania przez pracownika z urlopu.

Zakaz wypowiedzenia i rozwiązania umowy o pracę dotyczy wszystkich pracowników korzystających z urlopów związanych z rodzicielstwem, z wyjątkiem pracowników zatrudnionych na podstawie umowy na okres próbny nieprzekraczający jednego miesiąca. Nie ma on jednak charakteru jednolitego. Najsilniejsza ochrona dotyczy osób korzystających z urlopów: macierzyńskiego podstawowego i dodatkowego, urlopu na warunkach urlopu macierzyńskiego (podstawowego i dodatkowego), urlopu rodzicielskiego oraz urlopu ojcowskiego. Oznacza to, że pracodawca nie może wypowiedzieć umowy o pracę pracownikowi korzystającemu z takiego urlopu. Natomiast, jeżeli wypowiedzenie nastąpiło przed skorzystaniem przez pracownika z tego urlopu, a umowa miałaby się rozwiązać $w$ trakcie korzystania $z$ urlopu, to pracodawca powinien cofnąć oświadczenie woli o wypowiedzeniu. Rozwiązanie umowy o pracę z pracownikiem korzystającym $z$ jednego $z$ wymienionych urlopów jest dopuszczalne jedynie w przypadku upadłości bądź likwidacji pracodawcy. Możliwe jest również rozwiązanie umowy o pracę w trybie niezwłocznym z przyczyn zawinionych przez pracownika pod warunkiem, że zakładowa organizacja związkowa reprezentująca takiego pracownika wyraziła na to zgodę.

W odniesieniu do pracownika korzystającego z urlopu wychowawczego ochrona trwałości stosunku pracy jest nieco słabsza. Wprawdzie przepis art. $186^{1}$ k.p. zawiera sformułowanie, że w okresie od dnia złożenia wniosku o urlop wychowawczy do dnia zakończenia tego urlopu pracodawca nie może wypowiedzieć ani rozwiązać umowy o pracę z pracownikiem, ale $w \S 2$ tego przepisu wskazuje się, że jeśli wniosek o udzielenie urlopu został złożony już po dokonaniu czynności zmierzającej do rozwiązania umowy, to umowa rozwiązuje się 
w terminie wynikającym z tej czynności. Oznacza to, że złożenie wniosku o urlop po dokonaniu przez pracodawcę wypowiedzenia nie pociąga za sobą konieczności wycofania oświadczenia woli o wypowiedzeniu. W takim przypadku urlop wychowawczy trwa do dnia rozwiązania umowy. Poza tym pracodawca może rozwiązać umowę o pracę z pracownikiem korzystającym z urlopu wychowawczego nie tylko z powodu upadłości bądź likwidacji oraz z przyczyn zawinionych przez pracownika, lecz także w przypadku zwolnień grupowych z przyczyn niedotyczących pracowników określonych w ustawie z 13 marca 2003 r. o szczególnych zasadach rozwiązywania z pracownikami stosunków pracy z przyczyn niedotyczących pracowników ${ }^{18}$.

Jeszcze inaczej wygląda sytuacja pracownika uprawnionego do urlopu wychowawczego, który zamiast korzystać z urlopu złożył do pracodawcy wniosek o obniżenie wymiaru czasu pracy. W tym wypadku pracodawca nie może wypowiedzieć ani rozwiązać umowy o pracę w okresie od dnia złożenia wniosku do dnia powrotu do nieobniżonego wymiaru czasu pracy, nie dłużej jednak niż przez łączny okres 12 miesięcy. Rozwiązanie umowy w tym okresie może nastąpić z powodu upadłości bądź likwidacji, a także z przyczyn zawinionych przez pracownika. Pracodawca będzie mógł również wypowiedzieć pracownikowi umowę na podstawie cytowanej wcześniej ustawy o szczególnych zasadach rozwiązywania z pracownikami stosunków pracy z przyczyn niedotyczących pracowników i to zarówno w trybie zwolnień grupowych, jak i indywidualnych, przy czym w tym drugim przypadku tylko wtedy, gdy reprezentująca pracownika zakładowa organizacja związkowa nie złożyła sprzeciwu w terminie 14 dni od otrzymania od pracodawcy zawiadomienia o zamierzonym wypowiedzeniu (dotyczy to tylko pracowników zrzeszonych w związku zawodowym lub objętych ochroną związku).

Pracownicy, z którymi pracodawca w sposób niezgodny z prawem rozwiązał umowę o pracę, mogą wystąpić do sądu pracy z roszczeniem o przywrócenie do pracy. W takim wypadku sąd jest związany roszczeniem pracownika. Wyjątkowo tylko może orzec o odszkodowaniu, gdy przywrócenie do pracy jest niemożliwe z powodu upadłości bądź likwidacji pracodawcy. Co ważne, pracownikowi przywróconemu do pracy przysługuje wynagrodzenie za cały czas pozostawania bez pracy.

Zabezpieczenie interesów pracownika korzystającego z jednego z urlopów związanych z rodzicielstwem jest realizowane również w postaci gwarancji powrotu na stanowisko pracy po zakończeniu korzystania z urlopu. Zgodnie z art. $183^{2}$ k.p., pracodawca ma obowiązek zapewnić pracownikowi po zakończeniu urlopu macierzyńskiego podstawowego i dodatkowego oraz urlopu na warunkach urlopu macierzyńskiego (także dodatkowego) powrót do pracy na dotychczasowe stanowisko, a jeśli nie jest to możliwe - na stanowisko równorzędne ze stanowiskiem zajmowanym przed rozpoczęciem urlopu lub na inne stanowisko odpowiadające

18 Dz. U. 2003, 90, poz. 844 ze zm. 
jego kwalifikacjom zawodowym. Dotyczy to również pracownika powracającego do pracy po zakończeniu urlopu rodzicielskiego i ojcowskiego. Co istotne, pracownikowi przysługuje takie wynagrodzenie, jakie by otrzymywał, gdyby nie korzystał z urlopu. To oznacza, że pracodawca musi uwzględnić wszystkie zmiany w wysokości wynagrodzenia, do jakich doszło w zakładzie pracy w okresie, w którym pracownik przebywał na urlopie ${ }^{19}$.

Natomiast pracownik, który korzystał z urlopu wychowawczego ma zagwarantowany powrót do pracy na równi z pracownikami wracającymi po urlopie macierzyńskim, ale tylko w zakresie stanowiska pracy. Jeśli nie jest możliwe zapewnienie pracownikowi dotychczasowego stanowiska pracy, pracodawca powinien dopuścić pracownika do pracy na stanowisku równorzędnym z zajmowanym przed rozpoczęciem urlopu bądź na innym stanowisku odpowiadającym jego kwalifikacjom zawodowym. Słabsza jest natomiast ochrona dotycząca wynagrodzenia za pracę. Przepis art. $186^{4}$ k.p. gwarantuje pracownikowi jedynie wynagrodzenie nie niższe od wynagrodzenia za pracę przysługującego na dotychczasowym stanowisku pracy w dniu powrotu do pracy po zakończeniu urlopu ${ }^{20}$.

Wszystkie opisane rozwiązania prawne, zawarte w dziale ósmym Kodeksu pracy, nie są jedynymi uprawnieniami pracowniczymi sprzyjającymi realizacji obowiązków związanych ze sprawowaniem opieki nad dzieckiem. Regulacje wspomagające pracowników w tym zakresie można znaleźć także w innych działach kodeksu - m.in. w przepisach dotyczących czasu pracy i urlopów pracowniczych.

W zakresie przepisów regulujących czas pracy wskazać należy przede wszystkim na wybrane systemy czasu pracy, które szczególnie sprzyjają realizacji obowiązków rodzicielskich związanych z opieką nad dzieckiem. W literaturze jako jeden z takich systemów wymienia się zadaniowy czas pracy, w którym pracownik rozliczany jest $z$ wykonanych zadań, co pozwala mu na znaczną swobodę w organizowaniu czasu pracy ${ }^{21}$. W moim przekonaniu na uwagę zasługują jeszcze dwa inne systemy, które przynajmniej w pewnym zakresie pozwoliłyby obojgu pracującym rodzicom łączyć wykonywanie pracy i sprawowanie opieki nad dzieckiem. Chodzi o system pracy weekendowej i system skróconego tygodnia pracy. Przy założeniu, że jedno z rodziców pracowałoby w systemie weekendowym, a drugie w systemie skróconego tygodnia pracy w układzie od poniedziałku do czwartku, mogliby oni wymieniać się obowiązkami w zakresie opieki nad dzieckiem bez konieczności rezygnowania z pracy lub angażowania w opiekę nad dzieckiem osób trzecich. Taką możliwość dałoby też zatrudnienie pracownika w niepełnym wymiarze czasu pracy, zwłaszcza przy wykorzystaniu innej instytucji przewidzianej w przepisach o czasie pracy - indywidualnego rozkładu czasu pracy. Zgod-

19 M. NAŁĘCZ, Wydłużenie urlopu macierzyńskiego $i$ inne prorodzinne zmiany w prawie pracy, „Monitor Prawa Pracy” 2009, nr 2, s. 64-65.

20 Ibidem, s. 65.

21 Por. M Latos-MıkowsKa, op. cit., s. 226. 
nie $z$ art. 142 k.p., taki rozkład czasu pracy może być wprowadzony w każdym systemie czasu pracy na pisemny wniosek pracownika. Trzeba jednak pamiętać, że wniosek w tej sprawie nie ma charakteru wiążącego dla pracodawcy.

Nowelizacja Kodeksu pracy z dnia 12 lipca 2013 r.22 wprowadziła również możliwość zastosowania rozkładu czasu pracy przewidującego różne godziny rozpoczynania pracy $w$ dniach roboczych wynikających $z$ rozkładu, jak również określającego przedział czasu, w którym pracownik decyduje o godzinie rozpoczęcia pracy w takim dniu. Instytucję tę określa się mianem ruchomego czasu pracy. Nie ulega wątpliwości, że może być ona bardzo przydatna w łączeniu pracy zawodowej z obowiązkami rodzicielskimi, zwłaszcza godzeniu obowiązków w zakresie sprawowania opieki nad dzieckiem przez dwoje rodziców będących pracownikami. Ruchomy czas pracy może być wprowadzony na mocy układu zbiorowego pracy, ewentualnie porozumienia zbiorowego zawartego ze związkami zawodowymi albo innym przedstawicielstwem pracowniczym. Niezależnie od powyższego trybu można go również wprowadzić na pisemny wniosek pracownika.

Warto ponadto zwrócić uwagę, że ustawodawca chroni pracowników opiekujących się dzieckiem do lat czterech przed nadmiernymi obciążeniami wynikającymi z wykonywania pracy w systemach czasu pracy przewidujących normy czasu pracy dłuższe niż osiem godzin na dobę (system równoważnego czasu pracy, praca przy dozorze urządzeń i pilnowaniu mienia lub ochronie osób, system pracy weekendowej i skróconego tygodnia pracy). Zgodnie bowiem z regulacją art. 148 k.p., czas pracy takiego pracownika bez jego zgody nie może przekraczać 8 godzin. Godzi się podkreślić, że pracownik w takim wypadku zachowuje prawo do wynagrodzenia za czas nieprzepracowany w związku ze zmniejszeniem z tego powodu wymiaru czasu pracy.

Również przepisy urlopowe zawierają pewne rozwiązania służące wspomaganiu obowiązków rodzicielskich w zakresie opieki nad dzieckiem. Pracownik przebywający na urlopie macierzyńskim podstawowym i dodatkowym, urlopie na warunkach urlopu macierzyńskiego podstawowym i dodatkowym, urlopie rodzicielskim bądź na urlopie ojcowskim może jeszcze przedłużyć czas poświęcony na sprawowanie opieki nad dzieckiem dzięki możliwości wykorzystania urlopu wypoczynkowego bezpośrednio po zakończeniu urlopów związanych z rodzicielstwem. Wniosek złożony $w$ tej sprawie jest wiążący dla pracodawcy. Ponadto w przypadku, gdy pracownik nie może rozpocząć zaplanowanego urlopu wypoczynkowego z powodu nieobecności wynikającej z korzystania z jednego z wymienionych urlopów związanych z rodzicielstwem, pracodawca ma obowiązek przesunąć urlop i udzielić go pracownikowi w terminie późniejszym.

Kończąc przegląd regulacji prawa pracy wspomagających realizację obowiązków rodzicielskich w zakresie sprawowania opieki nad dzieckiem należy jeszcze wspomnieć o jednej z nietypowych form zatrudnienia, mianowicie o telepracy.

22 Dz. U. 2013, poz. 896. 
Jest to forma świadczenia pracy wyjątkowo sprzyjająca osobom opiekującym się dzieckiem ${ }^{23}$. Zgodnie $z$ art. $67^{5}$ k.p., jest to praca wykonywana regularnie poza zakładem pracy, z wykorzystaniem środków komunikacji elektronicznej. Telepraca może być wykonywana w różnych miejscach, w tym także w domu pracownika, na co wyraźnie wskazuje regulacja art. $67^{14} \S 2$ k.p. Istotą telepracy jest przekazywanie pracodawcy przez pracownika wyników pracy za pośrednictwem środków komunikowania się na odległość. Wynika stąd, że pracownik dysponuje znaczną swobodą w organizowaniu czasu swojego świadczenia pracy. Pracując w domu, ma możliwość dostosowania godzin wykonywania pracy do obowiązków związanych ze sprawowaniem opieki nad dzieckiem. Ta forma świadczenia pracy pozwala zatem łączyć pozostawanie w zatrudnieniu z wykonywaniem obowiązków rodzicielskich bez konieczności angażowania w opiekę nad dzieckiem osób trzecich.

Podsumowując przedstawioną analizę można powiedzieć, że polskie prawo pracy zawiera wiele rozwiązań prawnych sprzyjających realizacji obowiązków rodzicielskich w zakresie opieki nad dzieckiem. Można nawet pokusić się o stwierdzenie, że ustawodawca stara się realizować postulaty zawarte w encyklice Laborem exercens w szerszym zakresie, niż wynika to z rozważań Jana Pawła II, który przypisywał szczególną rolę $w$ budowaniu rodziny głównie kobietom. $Z$ regulacji zawartych w Kodeksie pracy wynika bowiem, że prawodawca aprobuje zaangażowanie mężczyzn w proces wychowywania dziecka, co przejawia się w przyznawaniu mężczyznom uprawnień, które do niedawna były zastrzeżone wyłącznie dla kobiet. Trzeba jednak podkreślić, że takie działania nie są jedynie wynikiem przemian społeczno-gospodarczych, lecz wiążą się również z koniecznością dostosowania prawa polskiego do standardów wyznaczanych przez prawo Unii Europejskiej, zwłaszcza przez tzw. dyrektywy równościowe.

${ }^{23}$ Por. D. Ksı̨żEK, Telepraca, „Praca i Zabezpieczenie Społeczne” 2004, nr 7, s. 10. 